\title{
correspondence
}

\section{Checks and balances}

Sir,--You raise the issue (Nature, September 6) of the role of journals in situations such as the proposed moratorium on plasmid engineering experiments. You conclude for two reasons that you should not, as a policy, refuse to publish any report of experiments that might be carried out in defiance of the call for postponement-this call, or others like it. Your two reasons were scientific variants of classic arguments against censorship: what referee can judge papers for their ethical standing? Why drive publication under ground? Yet you acknowledge implicitly the considerable power of journals such as yours to influence the standards -scientific, but perhaps ethical as well - of researchers. Is there a way to use your power not through editorial censorship but instead as an important auxiliary to the checks and balances that exist or may need to be set up in the scientific community? For a model, consider the statement you will find in the instructions to contributors to Proceedings of the National Academy of Sciences: "Manuscripts reporting experiments with humans should be accompanied by a copy of the document authorising the research by the responsible institutional committee."

American research hospitals and medical laboratories, as is generally known, have peer committees that must pass every plan for an experiment using human subjects, while there is still time - that is, before the experiment is begun. But one important aspect of the open letter by the American group was that the danger was imminent; as Paul Berg, a leader of the group, has said several times, many of the experiments at issue were already planned to be completed before the international meeting in February, and their dangers if any, reside not in some future consequence or application of published results but in the experiments themselves. Control must occur before the work, not merely before publication-not imprimatur but laboretur. The nuclear fission or "Hahn should not have published" analogy is misplaced. But many American and British biological laboratories, whose own people would be the first victims of an experiment gone wrong, are setting up biohazard or biological safety committees-scientific peer groups who will review research plans. Such review is decentralised, appropriately motivated, and can be done early enough; it is done not just by peers every couple of years (as with peer review of grant applications in the American setting) but from week to week by colleagues who ought to be familiar with men, their work, and their equipment. Such institutional structures seem to me to be admirably adaptable to part at least of the present problem. As local safety committees begin to function, to reinforce them with an editorial requirement that reports submitted for publication be accompanied by evidence that the local review was done-like the rule at $P N A S$ for human subjects - that would be a natural step with no taint of censorship.

$$
\begin{aligned}
& \text { Yours faithfully, } \\
& \text { HoRACE JUDSON }
\end{aligned}
$$

Manting House,

Meldreth House, Cambridgeshire

\section{Joke with whiskers}

SIR,-Martin C. Raff (Nature, 251, 184) describes nude mice which have spread through the immunological world at a remarkable pace. Should they be called squeakers?

Yours faithfully,

Rochdale, UK

$$
\text { M. A. Perkin }
$$

\section{For the birds}

SIR,-Dr W. R. P. Bourne in his article "Egg Collector Collected" (Nature, 249, 793, 1974) has done well to draw the scientific world's attention to the egg- and bird-collecting outrages regularly perpetrated by ornithologists, some of high repute, in North America. I can vouch for his reference to a "conspiracy of silence"; leading publications in the field have declined to publish any mention of this disturbing subject. It is perhaps time that the rest of the world was made aware of the North American situation.

One might imagine that the National Audubon Society (NAS) would take a stand against this. After all, in the early days, were not two Audubon wardens murdered in defending egret nests in Florida? Yet when in 1969 two biologists shot 1,000 egrets in that state in the space of four weeks ${ }^{1}$ this action was defended in a letter to me from the NAS by saying that it was all right because it was done by the "proper authorities".
What has been overlooked, however, is that experts in population dynamics (if experts they are) are not the only people with an interest in birds. To a great majority of people there are ethical and aesthetic considerations involved in taking the lives of so many beautiful and harmless creatures. This is perhaps an unscientific attitude; but birds do not belong to scientists and many people see no reason why, as in North America, ornithologists have some prescriptive right to kill them.

One might imagine that no ornithologist would raise any serious objection to a code that asked a collector to state, when applying for a permit, the nature of the scientific research he was engaged upon; what new information and understanding about avian biology he expected to gain from a study of his specimens; what species he required and how many; whether such information could be gained from a study of pre-existing specimens; and whether his collecting was likely to harm any population. The permit-issuing agency might then assess the scientific merit of the proposal and then issue a permit for a specified number of a named species for an approved purpose. Yet this suggestion has been repeatedly rejected by ornithologists in North America. Applicants are not obliged to state which species they wish to collect, open permits are issued without specifying which species may be shot or how many, and their holders may shoot any birds regardless of whether they are engaged in research on them or not.

Yours faithfully, J. B. TATUM

Department of Physics,

University of Victoria, British Columbia,

\section{Canada}

${ }^{1}$ Fogarty, M. J., and Hetrick, W. M., Auk, 90, 268 (1973).

\section{Blameworthy}

SIR,-In my article last week ('For those in peril on the factory floor') the Royal Society was unfortunately omitted from the list of organisations taking no interest in asbestosis and similar consequences of technology. In fact the Royal Society should have headed the list as the body with.the greatest influence but the least inclination to do anything about it.

Peter J. SMith 